Article title: Group Work and Distance Online Learning in Higher Education - Reflecting on the Covid-19 Experience in the Natural Sciences

Authors: Pillay Rajendran [1]

Affiliations: Nature Conservation, Faculty of Science, Mangosuthu University of Technology[1]

Orcid ids: 0000-0001-7193-3121[1]

Contact e-mail: rpillay23@gmail.com

License information: This work has been published open access under Creative Commons Attribution License http://creativecommons.org/licenses/by/4.0/, which permits unrestricted use, distribution, and reproduction in any medium, provided the original work is properly cited. Conditions, terms of use and publishing policy can be found at https://www.scienceopen.com/.

Preprint statement: This article is a preprint and has not been peer-reviewed, under consideration and submitted to UnisaRxiv for open peer review.

DOI: 10.25159/UnisaRxiv/000007.v1

Preprint first posted online: 27 April 2021

Keywords: group work, distance online learning, structured reflection 


\title{
Group Work And Distance Online Learning in Higher Education - Reflecting on the Covid-19 Experience in the Natural Sciences
}

\author{
Rajendran P. Pillay \\ https://orcid.org/0000-0001-7193-3121 \\ Mangosuthu University of Technology, South Africa \\ rpillay23@gmail.com \\ Pillay.Rajendran@mut.ac.za
}

\begin{abstract}
The sudden shift to online education at higher education institutions due to the Covid-19 pandemic had an impact on teaching and learning. For many the "new experience" meant learning or improving on the use of online technology in the distance mode. Although there have been many studies conducted on the impact of the pandemic on higher education, there is a paucity of research on specific pedagogies to mediate learning in the distance context, group work being one of them. This paper presents a reflective analysis of a case study in which group work was a pedagogical strategy used during the lockdown. Data collection involved questionnaires and a part transcript of a group's mobile synchronous text chat. The data were analysed qualitatively and quantitatively for the open and closed questions, respectively. The findings reveal mobile phones as the most common technological device used, the specific challenge of data and internet access on group work success, and the professional benefit of developing social skills even in a distance online context. The study confirms that group work is a viable pedagogical strategy to mediate distance online learning which requires the expert guidance of the lecturer and reflection by group members to improve their distance online interactions.
\end{abstract}

Keywords: group work, distance online learning, structured reflection

\section{Introduction}

The Covid-19 pandemic necessitated lockdowns had an impact on higher education globally through unplanned sudden shifts to online distance learning for the continuity of education. The sudden shift to online learning manifested complexities, some unique and some common to institutions (Hedding et al. 2020; König, Jäger-Biela, and Glutsch 2020; Mittal, Pani, and Thakur 2020). The lack of pre-existing policies mandating online learning, inequities, teacher inadequacy of skill in using technological tools and resources for virtual teaching in distance learning were some of the challenges faced at different levels of education (Chaka 2020; Sokal, Trudel, and Babb 2020; Mishra, Gupta, and Shree 2020). South Africa also experienced this impact. 
Although many studies have reported on the impact of the pandemic on higher education, there is a paucity of research on specific pedagogies in distance online learning; group work being one of them. The contribution of this reflective analysis of group work seeks to improve the quality of pedagogical mediation and prompt further reflection of its use in distance online learning. Pedagogical reasons to use group work include the co-construction of knowledge, a mimic of social practice through collaboration, and the development of skills for the workplace (Govender and Pillay 2018; Rafferty 2013). Distance online learning then cannot negate the value of group work to prepare graduates for the workplace and needs to be given significant attention. This paper reports on a case study of reflective analysis of group work attempted by an academic in the shift to distance online learning during the Covid-19 pandemic. Three research questions framed the study:

- In which way did the groups communicate, approach the tasks and interact in distance online learning during the lockdown?

- What were the views and experiences of the students on group work in distance online learning during the lockdown?

- What were the student reflections on group work in distance online learning tasks?

\section{Literature Review}

The rapid and disruptive introduction of digitisation exacerbated by the Covid-19 pandemic had an impact on university education (Dover 2020). Online learning is likely to dominate formal education as an imperative in the "new normal" and post the pandemic (Chaka 2020; Mittal, Pani, and Thakur 2020). Facilitators of education delivery will need to reflect on and rethink their pedagogical practices as online learning demands change from face-to-face modalities (Pather and Cupido 2020; Schneider and Meirovich 2020). Structured reflection using numerous sources provide authentic means of rethinking pedagogical practices. Structured critical reflection encompasses pedagogical issues and social and economic aspects that have an impact on pedagogical practices (Killen 2016). The sudden shift to distance online learning was implemented across a range of social and economic contexts.

\section{Open and Distance Learning}

Open and distance learning (ODL) can be considered a multidimensional concept that seeks to synergise time, geographical space, socio-economic, pedagogical and communication distance in the relational web of students, peers, academics and the curriculum (Unisa 2008). In South Africa, ODL institutions historically provided access to higher education for the majority of working students who previously experienced limitations to such access (Letseka and Pitsoe 2014). In the largest distance university in South Africa, post 2012, there was as a shift from postal correspondence of study 
materials towards online teaching and learning pedagogy (Murray, Byrne, and KoenigVisagie 2013).

The ODL framework is based on the assumption that every student's learning can be supported optimally by modern electronic technologies (Tsabedze and Ngoepe 2020). It is evident that there is increasing tendency for educators to experiment with open teaching and learning pedagogies and technologies to engage students in active learning (Zhang, Burgos, and Dwason 2019; Zhang, Li, and Liu 2019). However, globally this is not an equitable situation, as is evident in the resource challenges in sub-Saharan countries compared to economically developed countries (Tadlaoui and Chekour 2021).

In reality, ODL has its challenges, many of which became conspicuous in the forced shift to distance online learning at the onset of the COVID-19 pandemic. Online learning experiences can be synchronous, i.e. where academics, students and peers interact at the same time, or asynchronous, i.e. where interactions are independent and take place at different times using electronic devices with internet access (Sadiku, Adebo, and Musa 2018; Schneider and Meirovich 2020; Singh and Thurman 2019). Distance online learning is used as a specific reference point in this paper instead of blended learning, as the study reports on group work in a distance online learning context. Initial Covid19 lockdown regulations in South Africa sanctioned face-to-face education delivery modalities.

Blended or hybrid learning combines elements of the traditional face-to-face modality with those of open distance education and online learning, as was adopted in schools in Morocco owing to the Covid-19 pandemic (Tadlaoui and Chekour 2021). Johnson, Daum, and Norris (2021) point out that distance online education has implications when it is forced rather than it being a choice. In their study in the United States, issues relating to equity, marginalisation of practical subjects, learning pedagogy and accessibility emerged. Online teaching and learning pedagogies often have various challenges resulting in many academics avoiding innovative possibilities for active learning (Schneider and Meirovich 2020), group work being one of them.

\section{Group Work}

The ability of employees to work collaboratively is a much valued graduate attribute (McKinney and Cook 2018; Zhang, Burgos, and Dwason 2019; Zhang, Li, and Liu 2019). Group work is thus an effective constructivist pedagogy in higher education to develop students' cognition, personal, social and professional skills (Cartwright et al. 2021; Govender and Pillay 2018; Rafferty 2013) and scientific literacy skills (Auerbach and Schussler 2017; Zhang, Burgos, and Dwason 2019; Zhang, Li, and Liu 2019). Group work should involve both meaningful interaction and successful task completion (Chiriac 2014). However, it can be difficult for students to work together in an academic context (Cartwright et al. 2021; McKinney and Cook 2018; McKinney and Sen 2016), and group pedagogy may appear challenging to lecturers and students without much experience in distance online learning contexts. Even in face-to-face group work there 
are issues when working in a team. These include fairness in allocating the same mark even when there are unequal contributions by group members (Cartwright et al. 2021; Chiriac 2014; McKinney and Cook 2018). The positive impact of group work in faceto-face contexts has been widely reported (Cartwright et al. 2021; Govender and Pillay 2018; Zhang, Burgos, and Dwason 2019; Zhang, Li, and Liu 2019).

\section{Methodology}

A survey research design is useful to elicit participants' views, experiences and suggestions (Bertram and Christiansen 2018; Maree and Pietersen 2016), as was the intention in this case study. The participants were first- and second-year students from an undergraduate programme in the Natural Sciences. The students registered for a faceto-face mode of delivery of lectures and were taught by the same lecturer. The students responded individually to electronic questionnaires which included closed- and openended questions. One questionnaire was specifically designed for group leaders (to which four group leaders responded), a second questionnaire was designed for the students in two second semester modules (to which thirty-three students responded), and parts of a mobile text application transcript was provided by one group from a year one first semester module. The justification for using the three data collection strategies was to get an in-depth, valid and holistic reflective analysis to authentically contribute to the body of knowledge on group work in distance online learning.

The analysis followed a mixed-method approach, i.e. a quantitative analysis (descriptive statistics) and qualitative analysis (content analysis) to provide a complete understanding of the context (Ivankova, Creswell, and Clark 2016; Kumar 2014). The quantitative analysis involved expressing as a percentage the tallied responses to the survey questions where students needed to select from choices provided for statements on groupwork in distance online learning during the lockdown period. The qualitative analysis involved content analysis of the group interaction transcript and responses to open questions in the questionnaire for group leaders and for all students. In a preliminary analysis, thematic categories were identified in the responses followed by coding of the data according to the categories, for example collaborative learning and home backgrounds that are unconducive to learning.

A limitation of using all electronic questionnaires was that it was dependent on data and internet access. In addition, student response to the questionnaire was voluntary. It is likely that for these reasons all students did not respond. Ethical protocols were observed. The study was conducted under a research project registered with the university research directorate. 


\section{Findings}

\section{In which way did the Groups Communicate, Approach the Tasks and Interact in Distance Online Learning during the Lockdown?}

\section{Communication channels}

In the survey, the students listed a range of communication channels that they used to communicate with their group members such as messaging applications (Whatsapp groups), email, phone calls and cell phone video calls. According to the group leaders, the communication channel used most often was the WhatsApp group chat (both text and audio communication) as it was easy to use, cost effective, fast and interactive.

Approach to the tasks

The results of the survey $(n=32)$ indicated that dividing the questions among the members seemed to be the most favoured method when approaching the group work tasks $(65.6 \%)$, followed by all members contributing to the questions $(31.25 \%)$ and by one person doing all the work (3.1\%). These results were also confirmed by the group leaders' response which show that the way in which the tasks were approached varied in groups.

We divided questions and if one had a problem we worked together. (Group leader 1)

\section{Group interaction}

The transcript of one group provides evidence of the interaction taking place in the group. Although this is just one group, it makes the point that group work is a viable pedagogical strategy for distance online learning.

\section{Day 3}

How is the assessment going? Have you managed to start with it? (Student 1)

Hello guys . . . I started but may I please answers for $1.1 \ldots$ once am done I will send my table for some help. (Student 3)

That is the easiest answer. Chlorophyll, sunlight, water and carbon dioxide. (Student 1)

Thank you for confirming. (Student 3)

All the notes that [lecturer's name] gave is in the assessment. Please make use of it. (Student 1)

Day 4

Afternoon colleagues. Please don't only answer your selected questions. Read through the whole notes for better understanding. Thank you. (Student 1) 
If you need to be helped. I will assist you. (Student 1)

Thank you. (Student 2)

I am sorry guys I am still busy with the notes, will probably be done by tomorrow. (Student 4)

I'll send mine tomorrow I already did it but not properly it's draft I'll send you a picture tomorrow please bear with me. (Student 6)

That is great. We are all making progress. Excellent. (Student 1)

I will do the whole question or I will do 2.1 only . . . which is the table? (Student 4)

The whole of 2.1. (Student 1)

Thanks. (Student 4)

The transcripts of days 3 and 4 show evidence of collaborative learning. The student interactions show both clarification of content (day 3 - student 1's response to photosynthesis) and process (day 4 - student 4 seeking clarification on question number 2.1). However, 43 percent of the responses in the survey indicated some nonparticipation by group members $(n=32)$. Cooperation among the groups also varied as indicated by the opinions of the group leaders.

From my perspective the team was a bit slow on responding during the duration. If the assignment was due sooner, the team would have worked faster. (Group leader 3)

\section{What were the Views and Experiences of Students on Group Work in Distance Online Learning during the Lockdown?}

Table 1 shows the responses to the survey on students' views and experiences of aspects of distance online group work.

Table 1: Survey responses to students' views and experiences of distance and online learning group tasks

\begin{tabular}{|c|c|c|c|c|c|c|c|}
\hline \multirow{2}{*}{\multicolumn{2}{|c|}{ Question }} & \multicolumn{5}{|c|}{ Responses } & \multirow[t]{2}{*}{$n$} \\
\hline & & $\mathbf{S A}$ & $\mathbf{A}$ & $\mathbf{N}$ & D & SD & \\
\hline 1 & $\begin{array}{l}\text { Working in a group } \\
\text { inspired me to do my } \\
\text { best during the } \\
\text { lockdown/online } \\
\text { learning? }\end{array}$ & $\begin{array}{l}17 \\
(51.5 \%)\end{array}$ & $\begin{array}{l}8 \\
(24.24 \%)\end{array}$ & $\begin{array}{l}6 \\
(18.18 \%)\end{array}$ & $1(3 \%)$ & $1(3 \%)$ & 33 \\
\hline 2 & $\begin{array}{l}\text { I felt that group work } \\
\text { helped me to } \\
\text { understand the }\end{array}$ & $\begin{array}{l}10 \\
(32.2 \%)\end{array}$ & $\begin{array}{l}14 \\
(45.2 \%)\end{array}$ & $3(9.6 \%)$ & $\begin{array}{l}2 \\
(6.4 \%)\end{array}$ & $\begin{array}{l}2 \\
(6.4 \%)\end{array}$ & 31 \\
\hline
\end{tabular}




\begin{tabular}{|c|c|c|c|c|c|c|c|}
\hline \multirow{2}{*}{\multicolumn{2}{|c|}{ Question }} & \multicolumn{5}{|c|}{ Responses } & \multirow[t]{3}{*}{$n$} \\
\hline & & \multirow[t]{2}{*}{ SA } & \multirow[t]{2}{*}{$\mathbf{A}$} & \multirow[t]{2}{*}{$\mathbf{N}$} & \multirow[t]{2}{*}{ D } & \multirow[t]{2}{*}{ SD } & \\
\hline & content? & & & & & & \\
\hline 3 & $\begin{array}{l}\text { Did the lecturer } \\
\text { provide adequate } \\
\text { information (e.g. } \\
\text { worksheet with } \\
\text { instructions) for you to } \\
\text { do the group task? }\end{array}$ & $\begin{array}{l}27 \\
(81.8 \%)\end{array}$ & $\begin{array}{l}6 \\
(28.2 \%)\end{array}$ & - & - & - & 33 \\
\hline 4 & $\begin{array}{l}\text { What skills (if any) } \\
\text { did the group work } \\
\text { tasks assist you with to } \\
\text { strengthen or develop? }\end{array}$ & \multicolumn{5}{|c|}{$\begin{array}{l}\text { Scientific: } 16(50 \%) \\
\text { Social: } 23(71.8 \%) \\
\text { Communication: } 16(50 \%) \\
\text { Technological: } 6(18.75 \%)\end{array}$} & 32 \\
\hline 5 & $\begin{array}{l}\text { Overall how would } \\
\text { you describe your } \\
\text { group work } \\
\text { experience? }\end{array}$ & \multicolumn{5}{|c|}{$\begin{array}{l}\text { Positive: } 31(93.4 \%) \\
\text { Negative: } 2(6.5 \%)\end{array}$} & 33 \\
\hline
\end{tabular}

SA: strongly agree; A: agree; N: neutral; D: disagree; SD: strongly disagree

Group work, as in other settings, also assisted students in understanding the content of the course (a positive response of $77.4 \%, n=31)$. All students $(n=33)$ agreed that the lecturer provided adequate information to guide the task. This can be noted as a factor with potential to guide students towards success in distance online group work. Group work provides a pedagogical strategy to develop or strengthen various skills in students. The results $(n=32)$ indicate that group work mostly helped to develop or strengthen social skills $(71.8 \%)$. It is interesting that social skills were considered to be the most developed as this was a distance online experience and not a face-to-face one. Overall, in spite of the challenges students found the distance online experience to be inspiring and positive.

\section{What were Students' Reflections on Group Work in Distance Online Learning Tasks?}

Three key challenges were raised by students, namely, data and connectivity, noncooperation, and home backgrounds that are unconducive to learning. All three challenges have an impact on the success of pedagogical strategies such as group work.

It was not so easy to work at home, some of our parents do not understand the online learning and sometimes they send us to do their work as we were at home thus affecting our time and the way we work. (Group leader 4)

In the survey, the students provided recommendations of note to lecturers in the distance online context. A suggestion was that group members should receive marks on the basis of their contribution to the group. A punitive measure suggested was that a nonparticipating member's name should not appear on the final submission of the task. 


\section{Discussion}

Success of group work, although empirically reported (Cartwright et al. 2021; McKinney and Sen 2016), may not always be constant as contextual dynamics may differ. There is a difference between working in a group, i.e. students are in a group but work individually on separate parts of the task, and working as a group, i.e. where there is meaningful interaction (Chiriac 2014). Meaningful learning in small group work is more than being in a physical space or logging online; it is about collaboration and active learning (Killen 2016). In this study, group work in distance online learning revealed both working in a group (division of the task) and as a group (the collaboration evidenced in the group transcripts).

The students indicated that the mobile phone was the key device used and was the most pragmatic for communication given the circumstances. A mobile device can be used synchronously for group collaboration as shown in the group text transcription; a positive for distance online group work. However, Zhang, Burgos, and Dwason (2019) and Zhang, Li, and Liu (2019) aver that it is not just the technology that improves learning experiences but also the quality of match between the use of technology, the tasks and the student interaction. This study also shows that there were communication disgruntlements linked to functioning in the group. This included delays of immediate responses when required. In a study done by McKinney and Sen (2016), similar findings were reported where groups used electronic devices (such as smart phones).

In this study, the student feedback supported the assertions that they had developed or strengthened scientific and communication skills and to a larger extent social skills. One may question the finding of the high response to the development of social skills (71.8\%) in a distance online group work context. However, synchronous learning does not necessarily mean audio communication. It could also take the form of texting with immediate responses but it also requires etiquette. The group text transcripts provide evidence of this etiquette through greetings, for example, "good afternoon," through expression of gratitude, "thank you," and positive affirmation, "that's great." These social skills are also essential to professional teamwork (Govender and Pillay 2018; McKinney and Sen 2016; Rafferty 2013). This opposes the notion alluded to by Killen (2016) that online collaboration tasks should emphasise learning outcomes rather than the learning process.

The role of the lecturer or teacher cannot be overlooked in increasing the potential for successful group work (Killen 2016; Zhang, Burgos, and Dwason 2019; Zhang, Li, and Liu 2019). Potential issues associated with negative group work experiences could be circumvented through careful structuring of group work instructions and tasks (Cartwright et al. 2021). In this study, all the students were in agreement that the lecturer had provided adequate instruction and information on the distance online tasks. Zhang, Burgos, and Dwason (2019) and Zhang, Li, and Liu (2019) suggest that in collaborative group work the teacher can intervene where appropriate. The possibility exists that 
academics in higher education institutions can join in group chats as a facilitator more especially where groups request such guidance.

Research has shown that engaging students in structured reflection has benefits such as helping group members to understand their own and group practices to improve their future interaction (Killen 2016; McKinney and Sen 2016). The student reflections in this study focused on three areas to improve collaboration within the context of distance online learning, namely, increasing the range of communication channels, not delaying in doing tasks, and division of tasks. Given the challenges experienced in distance online learning, also expressed by students in a study on group work in a Business Intelligence module cited by McKinney and Sen (2016), increasing the range of communication channels may help to reduce communication challenges. In South Africa, network access and data challenges are widely cited as negatives to distance online learning, as indicated by the group leaders' inputs in this study.

Non-participation can be the cause of negative group work experiences (Cartwright et al. 2020; McKinney and Sen 2016). However, in this study, although students recommended punitive measures, non-participation cannot be totally justified as laziness. The students raised issues of data and internet access as problematic for their online group work interaction. Punitive measures would need to be cautiously considered in contexts of data and internet access inequities.

\section{Conclusion}

Group work cannot be ignored as a pedagogical strategy to support its value in the world of work. Although it may be argued that many of the student responses are aligned with group work tasks in face-to face learning, it is also confirmation that distance online learning can afford the similar benefits. There are avenues of technological communication for students to engage with each other in distance online learning. Data issues are a concern that cannot be ignored. However, it should not be a deterrent to distance online group work as education stakeholders seek to improve connectivity and access inequities.

\section{References}

Auerbach, Anna Jo, and Elisabeth E. Schussler. 2017. "Curriculum Alignment with 'Vision and Change' Improves Student Scientific Literacy.” CBE Life Science Education 16 (3): 19. https://doi.org/10.1187/cbe.16-04-0160.

Bertram, Carol, and Iben Christiansen. 2018. Understanding Research. Cape Town: Van Schaik. 
Cartwright, Nadia M., Payal Patil, Danyelle M. Liddle, Genevieve Newton, and Jennifer M. Monk. 2021. "Enhancement of Professional Behaviours and Perceptions of Critical Skill Job Preparedness through the Use of a Group Work Contract in Fourth-Year Nutritional Science Students." International Journal of Higher Education 10 (2): 27-41. https://doi.org/10.5430/ijhe.v10n2p27.

Chaka Chaka. 2020. "Higher Education Institutions and the Use of Online Instruction and Online Tools and Resources during the COVID-19 Outbreak - An Online Review of Selected U.S. and SA's Universities.” Research Square 1-46. https://doi.org/10.21203/rs.3.rs-61482/v1.

Chiriac, Eva Hammar. 2014. "Group Work as an Incentive for Learning - Students' Experiences of Group Work.” Frontiers of Psychology 5: 1-14. https://doi.org/10.3389/fpsyg.2014.00558.

Dover, Phillip. 2020. "Ivory Tower to the Ecosystem Driver: Transforming the University Business Model." In The University of the Future Responding to Covid-19, edited by Remenyi Dan, Grant Kenneth and Singh Shawren, 9-18. Pretoria: Van Schaik.

Kumar, Ranjit. 2014. Research Methodology. 4th ed. Los Angeles: Sage.

Govender, Samantha, and Rajendran P. Pillay. 2018. "University Students' Response to Group Work in Life Sciences - A Social and Cognitive Perspective." Journal of Educational Studies 17 (2): 42-59.

Hedding, David W., Michelle Greve, Gregory D. Breetzke, Werner Nel, and Bettine Jansen van Vuuren. 2020. "COVID-19 and the Academe in South Africa: Not Business as Usual." South African of Journal Science 116 (7/8): 1-3. https://doi.org/10.17159/sajs.2020/8298.

Ivankova Nataliya V., John W. Creswell, and Vikki L. Plano Clark. 2016. "Foundations and Approaches to Mixed Method Research." In First Steps in Research, edited by Kobus Maree, 306-336. Pretoria: Van Schaik.

Johnson, Josiah, David Daum, and Jason Norris. 2021. "I Need Help! Physical Educators Transition to Distance Learning during COVID-19." Physical Educator 78 (2): 119-37. https://doi.org/10.18666/TPE-2021-V78-I2-10866.

Killen, Roy. 2016. Teaching Strategies for Quality teaching and learning. Cape Town: Juta.

König, Johannes, Daniela J. Jäger-Biela, and Nina Glutsch. 2020. “Adapting to Online Teaching during COVID-19 School Closure: Teacher Education and Teacher Competence Effects among Early Career Teachers in Germany." European Journal of Teacher Education 43 (4): 608-22. https://doi.org/10.1080/02619768.2020.1809650.

Letseka, Moeketsi, and Victor Pitsoe. 2014. "The Challenges and Prospects of Access to Higher Education at UNISA.” Studies in Higher Education 39 (10): 1942-54. https://doi.org/10.1080/03075079.2013.823933. 
Maree, Kobus, and Jacques Pietersen. 2016. “Surveys and the Use of Questionnaires.” In First Steps in Research, edited by Kobus Maree, 173-190. Pretoria: Van Schaik.

McKinney, Pamella, and Chloe Cook. 2018. "Student Conceptions of Group Work: Visual Research into LIS Student Group Work Using the Draw-And-Write Technique.” Journal of Education for Library and Information Science 59 (4): 206-27. https://doi.org/10.3138/jelis.59.4.2018-0011.

McKinney, Pamela, and Barbara Sen. 2016. "The Use of Technology in Group-Work: A Situational Analysis of Students' Reflective Writing." Education for Information 32 (4): 375-96. https://doi.org/10.3233/EFI-160983.

Mittal Pankaj, and Sistla Rama Devi Pani, and Yogita Thakur. 2020. Protecting Academic Interest of Students During COVID-19 Pandemic - Sharing Best Practices. New Delhi: Association of Indian Universities.

Mishra Lokanath, Tushar Gupta, and Abha Shree. 2020. “Online Teaching-Learning in Higher Education during Lockdown Period of COVID-19 Pandemic.” International Journal of Educational Research Open 1: 1-8. https://doi.org/10.1016/j.ijedro.2020.100012.

Murray Jessica, Deirdre Byrne, and Leandra Koenig-Visagie. 2013. "Teaching Gender Studies via Open and Distance Learning in South Africa." Distance Education 20 (34): 339-52. https://doi.org/10.1080/01587919.2013.835775.

Pather, Sue, and Xena Cupido. 2020. "Understanding Academics' Adaptation to Learning and Teaching during a Crisis.” Proceedings of ICERI Conference, 3441-5. https://doi.org/10.21125/iceri.2020.0773.

Rafferty Patricia, D. 2013. "The Evaluation of MBA Group Work: A Case Study of Graduate Student Experiences and Perceptions of Positive Group Work Outcomes." Journal of Education for Business 88: 43-50. https://doi.org/10.1080/08832323.2011.638680.

Sadiku, Matthew N. O., Philip O. Adebo, and Sarhan M. Musa. 2018. "Online Teaching and Learning." International Journals of Advanced Research in Computer Science and Software Engineering 8 (2): 73-75. https://doi.org/10.23956/ijarcsse.v8i2.549.

Schneider, Naamati L., and A. Meirovich. 2020. "Student Guided Learning - from Teaching to E-Learning." Revista Romaneasca pentru Educatie Multidimensionala 12 (1Sup2): 11521. https://doi.org/10.18662/rrem/12.1sup1/254.

Singh, Vandana, and Alexander Thurman. 2019. "How Many Ways can We Define Online Learning? A Systematic Literature Review of Definitions of Online Learning (19882018)." American Journal of Distance Education 33 (4): 289-306. https://doi.org/10.1080/08923647.2019.1663082. 
Sokal, Laura, Lesley Eblie Trudel, and Jeff Babb. 2020. "Canadian Teachers' Attitudes toward Change, Efficacy, and Burnout during the COVID-19 Pandemic." International Journal of Educational Research Open 1. https://doi.org/10.1016/j.ijedro.2020.100016.

Tadlaoui, Mouenis Anouar, and Mohammed Chekour. 2021. "A Blended Learning Approach for Teaching Python Programming Language: Towards a Post Pandemic Pedagogy." International Journal of Advanced Computer Research 11 (52): 13-22. https://doi.org/10.19101/IJACR.2020.1048120.

Tsabedze, Vusi, and Mpho Ngoepe. 2020. "A Framework for Archives and Records Management Education in an Open Distance E-Learning Environment in eSwatini." Education for Information 36: 157-175. https://doi.org/10.3233/EFI-190294.

Unisa. 2008. Open distance learning policy. Pretoria: Unisa Press.

Zhang, Jingjing, Daniel Burgos, Shane Dwason. 2019. "Advancing Open, Flexible and Distance Learning through Learning Analytics." Distance Education 40 (3): 303-308. https://doi.org/10.1080/01587919.2019.1656151.

Zhang, Zhaoli, Yang Li, and Hai Liu. 2019. "Research on Collaborative Problem-Solving Supported by Multi-Screen and Multi-Touch Teaching System." International Journal of Information and Education Technology 9 (2): 105-109. https://doi.org/10.18178/ijiet.2019.9.2.1182. 